\title{
A correlation study between weather and atmosphere with COVID-19 pandemic in Islamabad, Pakistan
}

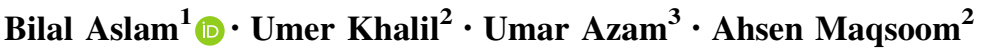

Received: 28 July 2020/Revised: 1 October 2020/Accepted: 6 October 2020/Published online: 16 October 2020

(C) Korean Spatial Information Society 2020

\begin{abstract}
The present research aims to investigate the association amid weather and the most recent pandemic of COVID-19 in Islamabad, the capital of Pakistan. The source of COVID-19 surveillance data for the secondary data analysis was the Pakistan's Ministry of National Health Services Regulations and Coordination. The weather data obtained from the Pakistan Metrological Department (PMD) was exercised in this research. The components of weather include wind speed $(\mathrm{m} / \mathrm{s})$, precipitation level ( $\mathrm{mm}$ ), normal, mean, maximum, and minimum temperature $\left({ }^{\circ} \mathrm{C}\right)$. For data analysis, a non-parametric correlation test was used due to the reason that normality was not satisfied. Precipitation level $(\mathrm{r}=-0.285 ; p=0.022)$, normal temperature $(\mathrm{r}=0.293 ; p=0.019)$ as well as the maximum temperature $(\mathrm{r}=0.347 ; p=0.005)$ were very much associated with COVID-19 virus. Pollution data (showing the concentration of $\mathrm{NO}_{2}$ ) of the specific region comprising the study area extracted from the Sentinel-5P satellite was also compared for the two years (2019 and
\end{abstract}

Bilal Aslam

bilalaslam45@gmail.com

Umer Khalil

umerkhali1745@gmail.com

Umar Azam

umarjuni011@gmail.com

Ahsen Maqsoom

ahsen.maqsoom@ciitwah.edu.pk

1 Department of Earth Sciences, Quaid-I-Azam University, Islamabad 45320, Pakistan

2 Department of Civil Engineering, COMSATS University Islamabad, Wah Campus, Wah Cantonment 47040, Pakistan

3 Department of Computer Science, COMSATS University Islamabad, Wah Campus, Wah Cantonment 47040, Pakistan
2020). Since the country will be entering to a new weather season, the conclusions may well assist the strategy and decision-makers in the deterrence of COVID-19.

Keywords COVID-19 · Health advisory · Precipitation level $\cdot$ Pollution data

\section{Introduction}

A third major epidemic of coronavirus $(\mathrm{CoV})$ infections is being faced by the world presently. In late 2019 a new $\mathrm{CoV}$ infection epidemic commenced in Wuhan, Hubei, China, which was initially called 2019-nCoV [1]. The Chinese administration, on the 7 of January 2020, declared a novel sort of pneumonia, coronavirus, with a complicated etiology [2]. Barely three months following the advent of this severe acute respiratory syndrome coronavirus 2 (SARSCoV-2), it was affirmed as a global pandemic owing to its quick spread. The COVID-19 pandemic was affirmed as the Sixth Public Health of Emergency Services (SPHEC) by the World Health Organization (WHO) on the 30 of January 2020 [3]. On the 11 of February 2020, it was renamed as COVID-19 by the WHO. The infection comprised asymptomatic or symptomatic manifestations, where a hefty percentage $(80 \%)$ of infections are insignificant or asymptomatic (no pneumonia manifestations) [4]. Slight to moderate respiratory illnesses, for instance, shortness of breath, coughing, and fever, are suffered by most of the people who get infected. Maximum estimations of the nurture phase for COVID-19 fluctuate from 1 to 14 days (d), very frequently about $5 \mathrm{~d}$ [5]. The infectivity can reason in severe acute respiratory syndrome, pneumonia, failure of kidney, and at times mortality in more severe cases [6]. The absolute common indication is fever 
$\left(<39.1{ }^{\circ} \mathrm{C}\right)$, and the second utmost common indication noted is cough [7]. Fatigue, headache, sore throat, gastrointestinal symptoms, and rhinorrhea are among other reported symptoms [8].

In Pakistan, on the 26 of February 2020, the Government of Pakistan's Ministry of Health verified the first-ever case of COVID-19 in Karachi, Sindh province. The Ministry of Health, on the same day, also confirmed another case in Islamabad. The sum of overall verified cases of COVID-19 touched 20 out of 471 doubted cases within 15 $\mathrm{d}$, with the maximum records in the Sindh province and then the Gilgit Baltistan region. The people who have confirmed the had one thing in common that is they had a fresh travel history from London, Syria, and Iran. As of the 1 of June 2020, the overall number of verified cases has reached 7,246,0, and presently, these cases are increasing by a high rate, and the situation is worst (Government of Pakistan). The bordering nations of Pakistan are profoundly pretentious, comprising China, where the COVID19 plague was initially undergone. Italy, in the west, has the maximum number of COVID-19 deaths, whereas after Italy, Iran, in the north, has a high number of deaths [9].

There are possibilities that the spread of the virus can be boosted due to extreme weather conditions, as proposed by Wang, Tang [10]. The potential spread of COVID-19 may also be predicated by seasonality and latitude [11]. Among the main viruses that affect the respiratory system of the human the coronavirus is listed as one [12]. Certain climatic conditions have even considered as predisposing factors by previous studies on respiratory diseases [13]. Consequently, for the interface among COVID-19 and people, the climate factors like wind speed, rainfall, and temperature might be biological catalysts in this particular situation of COVID-19. Numerous factors, comprising environmental determinants, population density [14], host defense mechanisms, host behavior, and virus infectivity [15], affects the transmission of the virus. The roles the environmental factors play on COVID-19 and their relative importance regarding the epidemic are still surrounded by uncertainties. Specifically, slight is known in countries like Pakistan which have four diverse weather spells where there is a considerable inconsistency of the change in weather among days. Therefore, in efforts against COVID19, this research will effectively contribute to policymaking as countries all around the world are ready to enter into new weather seasons and ease their lockdown methods consequently.

Even though the COVID-19 pandemic has caused calamities to human health all across the globe, but this calamity has produced surprising, encouraging effects for the environment and air quality. In developing nations, many of the cities are continuously experiencing worsening air quality conditions due to the ongoing urbanization and population growth in the past decades [16-18]. Criteria atmospheric pollutants which include oxides of nitrogen (NO and $\mathrm{NO}_{2}$ ), carbon monoxide $(\mathrm{CO})$, ozone $\left(\mathrm{O}_{3}\right)$, sulfur dioxide $\left(\mathrm{SO}_{2}\right)$, and particulate matter (PM), mostly the fine ones having an sleek thickness of less than and equal to $2.5 \mu \mathrm{m},\left(\mathrm{PM}_{2.5}\right)$, are the certain atmospheric pollutants which are identified as the ones causing harmful effects on cardiovascular and respiratory health [19, 20]. These adverse health effects intensify the symptoms of COVID$19[21,22]$.

Recently numerous studies have been carried out all across the world discussing different aspects of COVID-19. The prime focus of these studies was to highlight the most influencing factors on the transmission or spread of COVID-9. Various studies have considered atmospheric and metrological parameters in association with the COVID-19. The role of meteorological conditions and air pollution on the spread of COVID-19 in Italy's northern region, Lombardy, which was the regional epicenter of the pandemic outburst, was assessed quantitatively [23]. The Kendall rank and non-linear Spearman correlation tests were used for investigating the correlations among the air pollution, meteorological factors, and the COVID-19 virus. Similar correlation tests have also been used in another study [24]. In several cities of Latin America and the Caribbean region, the spread of COVID-19 was evaluated through a correlation among air pollution indicators $\left(\mathrm{NO}_{2}\right.$, $\mathrm{PM}_{2.5}$, and $\mathrm{PM}_{10}$ ) and climate (maximum, minimum, and average temperature, wind speed, average relative humidity, and rainfall) with the new cases of the COVID-19 on daily basis and the associated deaths [25]. For the qualitative analysis, the authors also considered poverty levels and income inequality. In Singapore, the relationship among the cases of COVID-19 pandemic and weather factors and the part of countries' warm tropical weather in the diffusion of COVID-19 was investigated [24]. The study used the secondary data of daily cases of COVID-19 from the webpage of Singapore's Health Ministry and for the investigation of the association among weather factors and COVID-19, Kendall rank and Spearman correlation tests were exploited.

In 122 cities of China, the meteorological factors, and the data of daily confirmed cases of COVID-19 were collected between 23 of January to 29 of February 2020 and to investigate the non-linear association among mean temperature and confirmed cases a generalized additive model (GAM) was operated [26]. A piecewise linear regression was also used to establish the association in a delegate manner. The enhancement in the quality of air in the two major cities of Ecuador, Quito, and Guayaquil owing to the reduced human activities as a result of the implemented quarantine measures [27]. In Oslo, the capital city of Norway, by employing a secondary data evaluation of 
weather and COVID-19 surveillance data obtained from the Norwegian Meteorological Institute and the Norwegian Public Health Institute, respectively, the correlation among COVID-19 pandemic and weather was analyzed by Menebo [28]. The main purpose of the present research is the analysis of the relation among weather and the COVID19 in Islamabad, Pakistan, with a novelty that it also considers the correlation among the atmosphere and the outbreak of the COVID-19 pandemic. This research analyzes how different weather situations favor or refrain the spread of the virus and the alterations in the quality of air due to the effects of imposed lockdown in the country. This research will be helpful for future pandemic planning or the next waves of COVID-19 in near future.

\section{Methods and materials}

\subsection{Study area}

Islamabad, the capital of Pakistan, which is situated in the north-west of the country in the Pothohar Plateau, was considered for the intended research (Fig. 1). The geographical coordinates of the capital city are $33^{\circ} 41^{\prime} 35^{\prime \prime} \mathrm{N} 73^{\circ} 03^{\prime} 50^{\prime \prime} \mathrm{E}$. It is denoted as Islamabad Capital Territory (ICT), though the formerly North-West Frontier Province (NWFP) (presently known as Khyber Pakhtunkhwa) and the Punjab region has historically shared this region in the past, it was built in the 1960s to replace the then capital city Karachi. Islamabad is a strategic city and lodges a unique location in the south of Margalla Hill ranges. In the urban area of Islamabad, the annual mean growth rate is $4.91 \%$. According to the 2017 census, the population of Islamabad city is 1,014,825 (Pakistan Bureau of Statistics). According to the Capital Development Authority (CDA), facts and figures, the urban region comprise an area of $220.15 \mathrm{~km}^{2}$ (85.00 sq. mi). With five varying seasons: Monsoon (July and August), Autumn (September and October), Winter (from November to February), Spring (March and April), and Summer (May and June), Islamabad has a humid subtropical climate. June is observed as the hottest month, where mean highs regularly surpass $38^{\circ} \mathrm{C}\left(100.4^{\circ} \mathrm{F}\right)$. In contrast, July is the wettest month in which showers and late afternoon thunderstorms with the chance of flooding and cloudburst are observed. On the contrary, January is the incredibly most refreshing month.

\subsection{Data sources}

Secondary data regarding cases of COVID-19 on daily basis was acquired from the Ministry of National Health Services Regulations and Coordination and weather data from the Pakistan Metrological Department (PMD) from the 1 of February to the 30 of July 2020. The constituents of weather include wind speed $(\mathrm{m} / \mathrm{s})$, precipitation level $(\mathrm{mm})$, normal, maximum, mean, and minimum temperature $\left({ }^{\circ} \mathrm{C}\right)$. The pollution data for the two cities

Fig. 1 Map of the study area

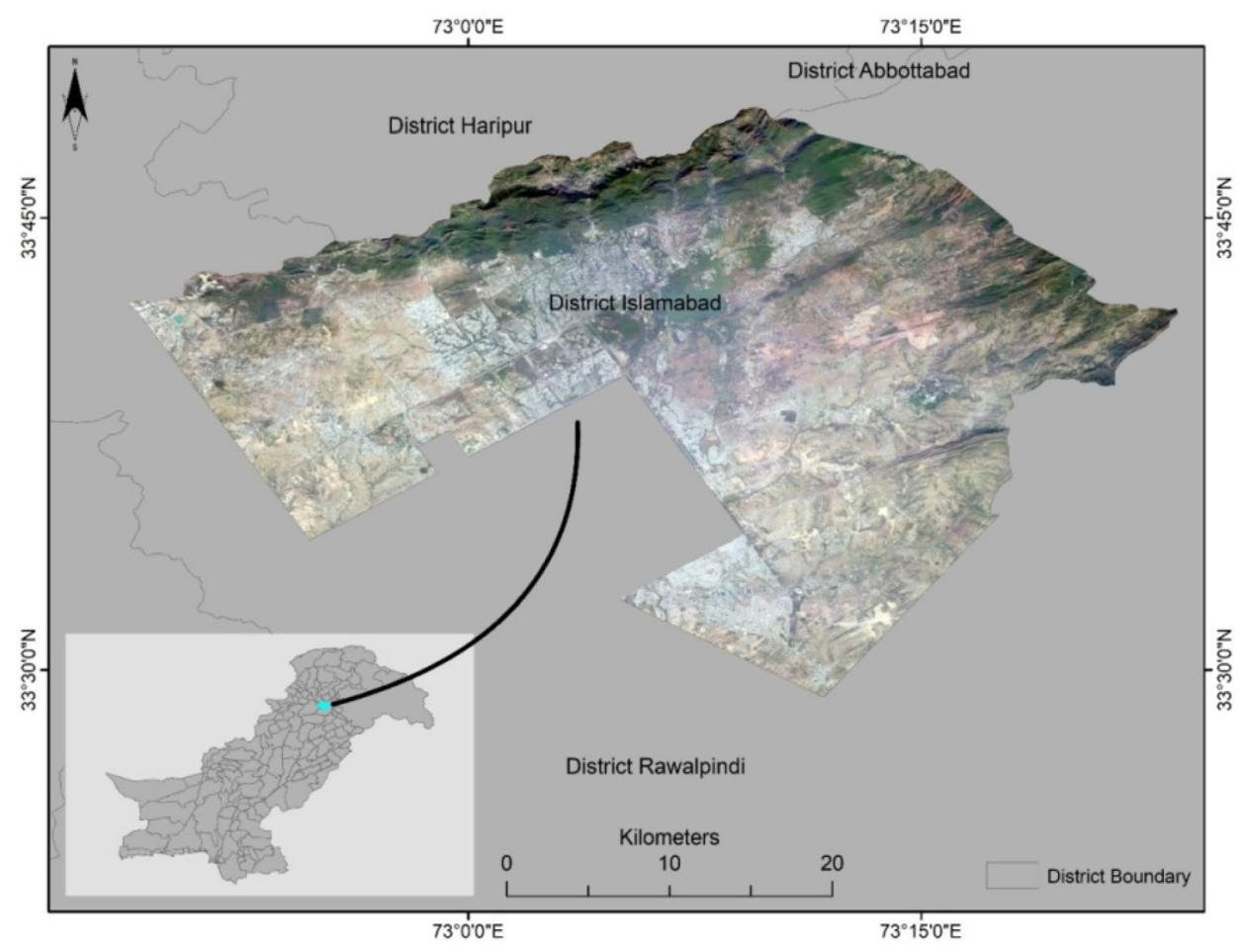


(concentration of $\mathrm{NO}_{2}$ ) was obtained from the Sentinel-5P satellite. The pollution data (which was the mean monthly data) was collected for two years, 2019 and 2020, ranging from 1 of February to the 30 of July.

\subsection{Data analysis}

For the variable "number of additional cases of COVID-19 on daily basis" the underlying supposition of Pearson's correlation was not satisfied (Shapiro-Wilk test of normality, $p<0.0001)$. Hence, to ascertain the associations among the weather components and COVID-19 pandemic, the non-parametric correlation estimation (Spearman correlation coefficient) was exercised. A bivariate, two-tailed assessment at a $95 \%$ confidence interval was utilized. The satellite data from Sentinel-5P indicates air pollution, which is the concentration of $\mathrm{NO}_{2}$ in the air. The data for the period of 1 of February to the 30 of July for two consecutive years was compared to have an overview of the variation in concentration.

\section{Results and discussion}

In this current research, an association among COVID-19 daily cases and the weather conditions was estimated. The daily new case data of COVID-19 was used from 1 of February to the 30 of July 2020. In the first days of March, the increase in new cases on daily basis was very less. Until the end of April, the increase in new cases on daily basis was moderate. The new COVID-19 cases started increasing very quickly in Islamabad during May, as evident from Fig. 2a. In June, the daily reported new cases were at a peak with more than 100 hundred cases every day. By the end of June, the peak started to get normalized with a decrease in the new daily cases due to the effective strategies of the Government. After this, the daily reported cases decreased gradually and continued the same pattern until the end of July. An illustrative outline of the weather data reveals a minimum temperature of $12{ }^{\circ} \mathrm{C}$ and the peak maximum temperature of $34{ }^{\circ} \mathrm{C}$ through the research phase (Table 1). Additionally, the least documented rainfall was $0 \mathrm{~mm}$, whereas $47 \mathrm{~mm}$ was the utmost recorded precipitation that was observed in the month of July 2020, as evident from Fig. $2 \mathrm{c}$ and Table 1. The recorded highest wind speed was $4.6 \mathrm{~m} / \mathrm{s}$, and the lowest wind speed was $0.5 \mathrm{~m} / \mathrm{s}$, as portrayed in Table 1 .

Maximum temperature $(\mathrm{r}=0.332 ; p=005)$, and normal temperature $(\mathrm{r}=0.254 ; p=0.019)$ were absolutely and expressively correlated with COVID-19 among the seven weather variables. On the contrary, there was a negative and meaningful association between the precipitation and the COVID-19. Though, the remaining weather variables comprising the highest wind speed, wind speed, average temperature, and minimum temperature were not expressively correlated with COVID-19.

In the current research, a picture of the incidence of COVID-19 in Islamabad is provided due to the pattern of climate change. A fragment of primary evidence is obtained to state that low levels of low precipitation and high temperatures (normal and maximum) confederate with the occurrence of COVID-19 as evident from Table 2 . This connotation is consistent with the former investigation that indicates the influence of precipitation, arid climate, and temperature on human West Nile virus infections $[29,30]$. Also, these findings significantly agree with the outcomes of research conducted by Menebo [28] in Oslo, Norway, where the author investigated the relationship of weather components and the COIVID-19 daily new cases. For the confident association among the COVID-19 daily new cases and temperature, multiple arguments can be specified. One argument could be a hypothesis that during the sunny day, folks are additionally inclined to breach lockdown "stay-home" rules, so as a result, they become susceptible to the virus. On the contrary, among the observed new cases on daily basis and precipitation, the negative relationship is the opposite as the folks would prevent going out if there is rainfall outside, so here the "stay-home" rules are followed eventually.

Moreover, the research conducted in 122 cities from China investigating the association among ambient temperature and COVID-19 virus revealed that mean temperature has an affirmative direct relation with the COVID-19 cases having a threshold of $3{ }^{\circ} \mathrm{C}$ [26]. The Kendall rank and Spearman correlation tests were exploited to probe the correlation among meteorological parameters and COVID19 in Singapore, and the outcomes exhibited that there is a substantial positive correlation among the temperature, relative humidity, absolute humidity, dew point, and water vapor with COVID-19 pandemic [24]. The aforementioned correlation tests were also used for research in Italy where the influence of weather and air pollution on diffusion of COVID-19 was investigated, and the findings highlighted a negative correlation among the virus transmission and the temperature and humidity related variables, whereas a positive correlation with air pollution $\left(\mathrm{PM}_{2.5}\right)$. The results of the research carried out in numerous metropolises in Latin America, and the Caribbean showed that minimum temperature, average temperature, and the quality of air were considerably related with the extent of COVID-19. Moreover, wind speed, humidity, and rainfall demonstrated a substantial association with everyday cases, overall cases, and death for numerous metropolises. Furthermore, income inequality and poverty levels were among those variables that were also deemed for qualitative assessment, and they 

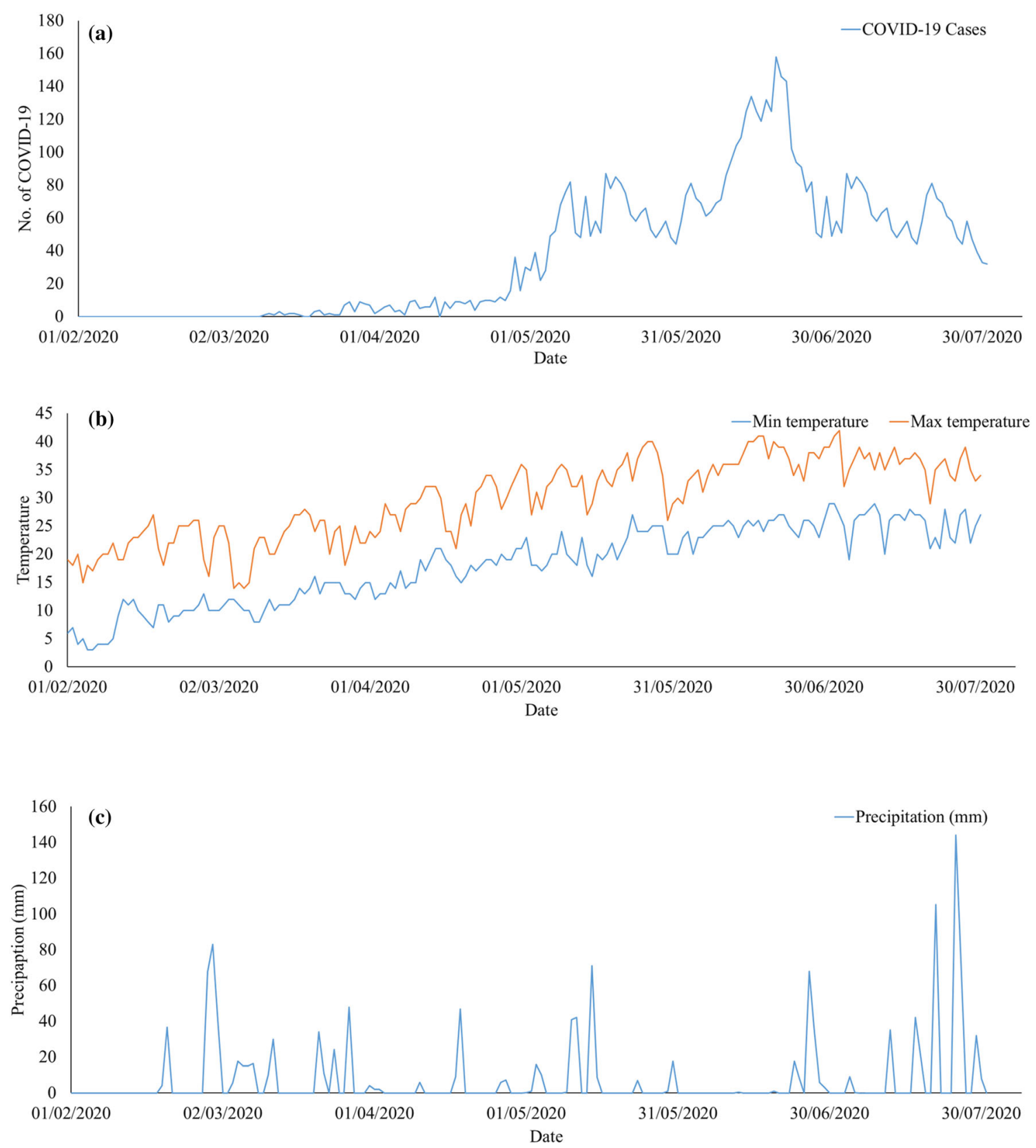

Fig. 2 Weather and COVID-19 correlation a Daily new cases of the COVID-19, b maximum and minimum temperature $\left({ }^{\circ} \mathrm{C}\right)$, $\mathbf{c}$ precipitation $(\mathrm{mm})$, in Islamabad, Pakistan from 1 of February to the 30 of July 2020

showed positive and negative association with the extent of COVID-19, correspondingly [25].

The repercussions in this investigation contradict the latest discovery from China by [10], where their study claimed that the transmission COVID-19 is reduced due to high humidity and high temperature. Some of the present studies contradict the findings of this study, and some are portraying similar results. One of the reasons might be the different local environmental and meteorological conditions. To resolve the query of "when or where it is/is not weather imperative on affecting COVID-19 prevalence?' necessitates an exploration of a controlling variable of the impact.

Despite the weather, in big cities like Islamabad, it is thought that the contribution to new COVID-19 cases is much more due to factors like household condition, population density, and high mobility. As the capital city of Pakistan, Islamabad, for job explorers who come from different cities of the country, is the central commercial destination, making it the swiftly foremost developing city in the country presently. Another reason for the fast transmissions of COVID-19 is that the population density 
Table 1 Explanatory statistics of different variables

\begin{tabular}{llll}
\hline Variables & Minimum & Maximum & Mean \\
\hline Daily new cases & 0 & 160 & 37 \\
Min temperature $\left({ }^{\circ} \mathrm{C}\right)$ & 12 & 21 & 16.96 \\
Max temperature $\left({ }^{\circ} \mathrm{C}\right)$ & 21 & 34 & 28.5 \\
Average temperature $\left({ }^{\circ} \mathrm{C}\right)$ & 14 & 36 & 20.45 \\
Normal temperature $\left({ }^{\circ} \mathrm{C}\right)$ & 11 & 35 & 19.47 \\
Precipitation $(\mathrm{mm})$ & 0 & 47 & 2.65 \\
Wind speed $(\mathrm{m} / \mathrm{s})$ & 0.5 & 4.6 & 2.31 \\
Highest wind speed $(\mathrm{m} / \mathrm{s})$ & 1.6 & 5.9 & 4.56 \\
\hline
\end{tabular}

of Islamabad is also very high. The city area of Islamabad has a population density of $2,089 / \mathrm{km} 2(5,410 / \mathrm{sq}$. mi) (Pakistan Bureau of Statistics). The population density like this allows the rapid spread of COVID-19 [31].

As the corona cases in the country started to increase, the Government of Pakistan, even with fewer resources to contain the spread of the virus, took rigorous measures like awareness campaigns, quarantine facilities, laboratories for testing, designed specialized hospitals, and imposed a lockdown. As the lockdown was enforced, the activities that were associated with humans were ceased. These human-associated activities include mostly those that are responsible for environmental pollution, for instance, the consumption of natural resources (oil, gas, wood, etc.) in industries and automobiles. Due to the less consumption of resources, environmental pollution decreased during the quarantine period as people prefer to stay inside. The air quality is indicated by the concentration of $\mathrm{NO}_{2}$ present in the air. The data extracted from the Sentinel-5P satellite was used to draw the results, which showed the concentration of $\mathrm{NO}_{2}$ in the air over the study area. The data was extracted for the two consecutive years to have a comparison. The intensity of $\mathrm{NO}_{2}$ was measured from 1 of February to the 30 of July for both 2019 and 2020, as shown in Fig. 3. The comparison reveals that there is a substantial decline in the intensity of $\mathrm{NO}_{2}$ in the air, specifically for the month of May when the country was experiencing a lockdown, thus increase in the quality of the air. The graph highlights that the capital city underwent a drastic improvement in the quality of the air due to the decrease in the intensity of $\mathrm{NO}_{2}$. This reduction in the concentration of the $\mathrm{NO}_{2}$ in the air was due to the reduced emission of pollution gases from industries and automobiles, which were ceased as a result of the enforced lockdown by the Government of Pakistan.

The emission of greenhouse gases and the air pollutants have decreased considerably due to the enforcement of protective quarantine, specifically closures of shopping centers and factories, limitations on transportation, and travel all over the world [32, 33]. In contrast, recent research in Tehran narrated an upsurge in the concentrations of $\mathrm{PM}_{10}$ and $\mathrm{PM}_{2.5}$ owing to an increase in the usage of private cars during the quarantine [34]. Studies performed in various territories of China have demonstrated that stringent COVID-19 control strategies substantially decreased intensities of certain toxins excluding ozone $[35,36]$. Due to the restrictions on economic and transport activities, the associated emissions decreased with the most considerable reduction in $\mathrm{CO}(20-36 \%)$ and $\mathrm{NO}_{2}$ $(30-52.8 \%)$ [36, 37]. Moreover, in China, due to the COVID-19 pandemic, the economic slowdown has also resulted in as minimum as $25 \%$ drop in carbon dioxide $\left(\mathrm{CO}_{2}\right)$ discharges later in January, which accounted for a total 6\% drop in worldwide emissions [32]. In Quito, the capital of Ecuador, the effect of constrained human pursuits on the air quality of urban areas demonstrated substantial decreases in the intensities of $\mathrm{PM}_{2.5}(-29 \%), \mathrm{CO}(-38 \%)$, $\mathrm{SO} 2(-48 \%)$, and NO2 $(-68 \%)$ during the first month of quarantine [27].

This research brings about additional comprehension regarding the association of new COVID-19 cases and weather components and can aid regional decision and policy making to contain the spread of the virus. Though, this investigation still has its confines: Mainly, the
Table 2 Relationship among the weather components and the new cases of COVID-19 on daily basis

\begin{tabular}{lc}
\hline Weather factors & Spearman's correlation coefficient $(\mathrm{r})$ \\
\hline Minimum temperature $\left({ }^{\circ} \mathrm{C}\right)$ & 0.052 \\
Maximum temperature $\left({ }^{\circ} \mathrm{C}\right)$ & $0.332^{\mathrm{a}}$ \\
Average temperature $\left({ }^{\circ} \mathrm{C}\right)$ & 0.217 \\
Normal temperature $\left({ }^{\circ} \mathrm{C}\right)$ & $0.254^{\mathrm{b}}$ \\
Precipitation $(\mathrm{mm})$ measured at $07 \mathrm{am}$ & $-0.237^{\mathrm{b}}$ \\
Wind speed $(\mathrm{m} / \mathrm{s})$ & 0.161 \\
Highest wind speed $(\mathrm{m} / \mathrm{s})$ & 0.215 \\
\hline
\end{tabular}

${ }^{\mathrm{a}}$ Correlation is substantial at the stage of 0.01

${ }^{b}$ Correlation is substantial at the stage of 0.05 
Table 3 Postulations of Daily new cases, Test date, Infection date, and Weather data corresponding progression and correlational assessment of outcomes in four postulations

\begin{tabular}{|c|c|c|c|c|c|}
\hline & \multicolumn{5}{|l|}{ Daily new cases } \\
\hline & $\begin{array}{l}\text { Test } \\
\text { date }=\text { Infection } \\
\text { date }\end{array}$ & $\begin{array}{l}\text { Test } \\
\text { date }=\text { Infection } \\
\text { date }+5 \mathrm{~d}\end{array}$ & $\begin{array}{l}\text { Test } \\
\text { date }=\text { Infection } \\
\text { date }+6 \mathrm{~d}\end{array}$ & $\begin{array}{l}\text { Test } \\
\text { date }=\text { Infection } \\
\text { date }+14 d\end{array}$ & $\begin{array}{l}\text { Amongst the data samples, a few could have } \\
\text { been tested at } 5 \text {, others at } 6 \text {, or others } \\
\text { remaining at } 14 \text { and a few at unfamiliar } \\
\text { incubation days }\end{array}$ \\
\hline $\begin{array}{l}\text { Minimum } \\
\text { temperature } \\
\left({ }^{\circ} \mathrm{C}\right)\end{array}$ & 0.052 & 0.068 & 0.058 & -0.012 & $\begin{array}{l}\text { Limitation (Future studies could employ } \\
\text { Vector Auto Regressive Models) }\end{array}$ \\
\hline $\begin{array}{l}\text { Maximum } \\
\text { temperature } \\
\left({ }^{\circ} \mathrm{C}\right)\end{array}$ & $0.332^{\mathrm{a}}$ & $0.192(p=.081)$ & 0.11 & -0.011 & \\
\hline $\begin{array}{l}\text { Average } \\
\text { temperature } \\
\left({ }^{\circ} \mathrm{C}\right)\end{array}$ & 0.217 & 0.102 & 0.092 & -0.073 & \\
\hline $\begin{array}{l}\text { Normal } \\
\text { temperature } \\
\left({ }^{\circ} \mathrm{C}\right)\end{array}$ & $0.254^{\mathrm{b}}$ & $0.262^{\mathrm{b}}$ & $0.252^{\mathrm{b}}$ & $0.174^{\mathrm{b}}$ & \\
\hline Precipitation(mm) & $-0.237^{\mathrm{b}}$ & -0.128 & $-0.179^{b}$ & -0.174 & \\
\hline Wind speed $(\mathrm{m} / \mathrm{s})$ & 0.161 & 0.121 & 0.111 & -0.094 & \\
\hline $\begin{array}{l}\text { Highest wind } \\
\text { speed }(\mathrm{m} / \mathrm{s})\end{array}$ & 0.215 & 0.163 & 0.053 & -0.098 & \\
\hline
\end{tabular}

Postulations of corresponding Daily new cases, Test date, Infection date, and Weather data was obtained earlier to the correlational examination. In the first column the presented results undertake that testing for the virus was performed deprived of the condition of any signs as an obligation for testing (e.g., communal testing crusades). As of this situation, it may perhaps be that the testing date and the infection date for the virus are similar. Consequently, weather data on the date of the test was deliberated in the investigation. Furthermore, incubation period of 5,6 , and $14 \mathrm{~d}$ were pondered with the infection date. Since the worldwide recommendations by the health community were that only those people who have acute symptoms of respiratory tract infection such as those people who have coughing, fever, difficulties in breathing, or who according to a doctor might have COVID-19, should be tested. In this situation, 5, 6, or $14 \mathrm{~d}$ were considered as the infection date (5-6 d of incubation period for corona are common) before the date of the test. Consequently, in columns 2, 3, and 5 the weather data for $5 \mathrm{~d}, 6 \mathrm{~d}$, or $14 \mathrm{~d}$ prior to the date of the testing was studied in the correlation examination correspondingly

${ }^{a}$ Correlation is substantial at the stage of 0.01

${ }^{\mathrm{b}}$ Correlation is substantial at the stage of 0.05

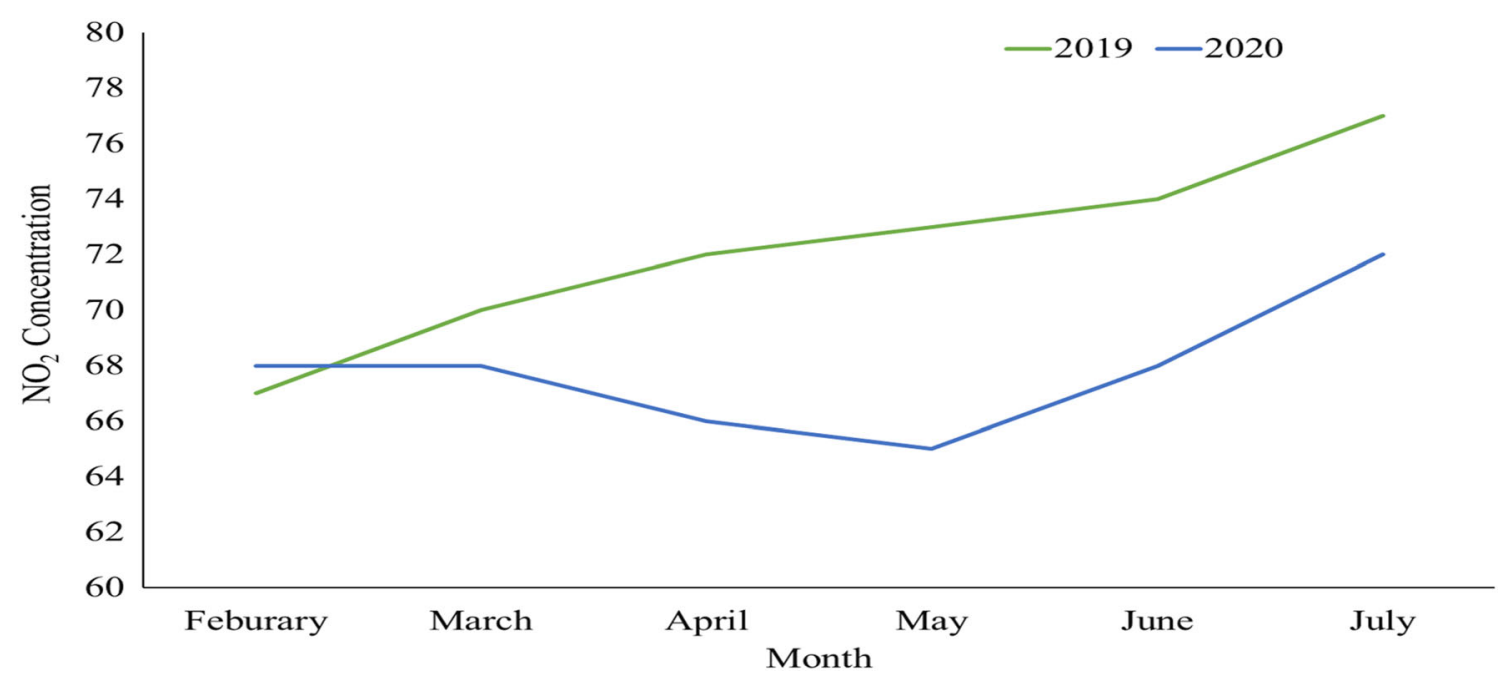

Fig. $3 \mathrm{NO}_{2}$ concentration from 1 of February to the 30 of July 2020 
influence of other key factors, like the development of herd immunities, testing capacities, lockdown implementation, and sanitization attitudes, which could have expressively prejudiced the core association was not accounted for. Furthermore, a linear association was supposed during the correlational analysis among the two correlating variables. In this investigation, test dates (cases of COVID-19 on daily basis) could not precisely infer infection dates (or the dates of getting the virus). It might be conceivable that the same date of getting the infection or a delay of incubation period is inferred by the regular cases of COVID-19 testified on the testing dates. Therefore, it introduces another limitation of the study because it is ill-defined that for which date the weather data is to be collected to correspond with the new cases on daily basis. As an intrusion to this setback, a comparison with the main correlational analysis was done by conducting three supplementary correlational associations supposing weather data from 5,6 , or $14 \mathrm{~d}$ (COVID-19 nurture stages) before the dates the regular corona cases were testified (Table 3). Among the daily new cases and normal temperature $\left({ }^{\circ} \mathrm{C}\right)$, the association importance is steady in all the four situations, whereas among the daily corona cases and the precipitation $(\mathrm{mm})$, the association importance is constant in the two situations.

\section{Conclusion}

The findings of this study indicate that the occurrence frequency of COVID-19 cases on daily basis correlates with precipitation and temperature in Islamabad, Pakistan. There is an affirmative connotation between the maximum temperature, normal temperature, and COVID-19. However, the observed relationship between COVID-19 and precipitation is negative. Another proposition might be that rainy weather as compared to sunny weather supports the "stay-home" rules. The air pollution situation (concentration of $\mathrm{NO}_{2}$ ) in the region seems to be improved considerably due to the imposed lockdown in the wake of COVID-19. The findings of this investigation could help the policymakers to plan accordingly for the future to cope with this virus (COVID-19). The desirable measures, for instance, lockdown, social distancing, staying at homes, using the face mask, sanitizers when essential, should be taken to regulate the worsening situation.

Author contributions B.A. (Graduate student) conceptualization, software, and data curation. U.K. (Graduate student) methodology and writing-preparation of the original draft. U.A. (Graduate student) validation and review-editing of the prepared draft. A.M. (Assistant professor) conceptualization, formal analysis, and project administration.

\section{References}

1. Zhu, N., Zhang, D., Wang, W., Li, X., Yang, B., Song, J., et al. (2020). A novel coronavirus from patients with pneumonia in China, 2019. New England Journal of Medicine., 382(8), 727-733.

2. WHO, (2020). Retrieved from https://www.who.int/csr/don/05january-2020-pneumonia-of-unkown-cause-china/en/.

3. Bilgin, S., Kurtkulagi, O., Kahveci, G. B., Duman, T. T., \& Tel, B. M. A. (2020). Millennium pandemic: a review of coronavirus disease (COVID-19). Experimental Biomedical Research., 3(2), $117-125$.

4. WHO, (2020). Coronavirus disease 2019 (COVID-19) situation report - 41. Retrieved from. https://www.who.int/docs/defaultsource/coronaviruse/situation-reports/20200301-sitrep-41-covid19.pdf?sfvrsn=6768306d_2.

5. Linton, N. M., Kobayashi, T., Yang, Y., Hayashi, K., Akhmetzhanov, A. R., Jung, S. M., et al. (2020). Incubation period and other epidemiological characteristics of 2019 novel coronavirus infections with right truncation: a statistical analysis of publicly available case data. Journal of clinical medicine, 9(2), 538.

6. Cheng, Y., Luo, R., Wang, K., Zhang, M., Wang, Z., Dong, L., et al. (2020). Kidney disease is associated with in-hospital death of patients with COVID-19. Kidney international., 97(5), 829-838.

7. Gu, J., Han, B., \& Wang, J. (2020). COVID-19: Gastrointestinal manifestations and potential fecal-oral transmission. Gastroenterology, 158(6), 1518-1519.

8. Michelen, M,. Jones, N., \& Stavropoulou, C. (2020). In patients of COVID-19, what are the symptoms and clinical features of mild and moderate cases. Centre for Evidence-Based Medicine https://www.cebm.net/covid-19/in-patients-of-covid-19-whatare-the-symptoms-and-clinical-features-of-mild-andmoderate case/accessed. vol. 16.

9. Saqlain, M., Munir, M.M., Ahmed, A. et al. (2020). Is Pakistan prepared to tackle the coronavirus epidemic? Drugs Ther Perspect, 36, 213-214. https://doi.org/10.1007/s40267-020-00721-1.

10. Wang, J., Tang, K., Feng, K., \& Lv, W. (2020). High temperature and high humidity reduce the transmission of COVID-19. Available at SSRN 3551767. 2020.

11. Sajadi, M.M., Habibzadeh, P., Vintzileos, A., Shokouhi, S., Miralles-Wilhelm, F., \& Amoroso, A. (2020). Temperature and latitude analysis to predict potential spread and seasonality for COVID-19. Available at SSRN 3550308.

12. Hoehl, S., Rabenau, H., Berger, A., Kortenbusch, M., Cinatl, J., Bojkova, D., et al. (2020). Evidence of SARS-CoV-2 infection in returning travelers from Wuhan China. New England Journal of Medicine., 382(13), 1278-1280.

13. D’Amato, G., Cecchi, L., D’Amato, M., \& Annesi-Maesano, I. (2014). Climate change and respiratory diseases. European Respiratory Society, 23, 161-169.

14. Brown, H. E., Childs, J. E., Diuk-Wasser, M. A., \& Fish, D. (2008). Ecologic factors associated with West Nile virus transmission, northeastern United States. Emerging infectious diseases., 14(10), 1539.

15. Cory, J. S. (2015). Insect virus transmission: Different routes to persistence. Current Opinion in Insect Science., 8, 130-135.

16. UN, (2015). 2015 revision of world population prospects. United Nations. New York. Retrieved from. https://www.un.org/devel opment/desa/ageing/news/2015/08/2015-revision-of-world-popu lation-prospects.

17. Limb, M. (2016). Half of wealthy and $98 \%$ of poorer cities breach air quality guidelines. The British Medical Journal, 353, i2730. https://doi.org/10.1136/bmj.i2730. 
18. WHO, (2016). Air pollution levels rising in many of the world's poorest cities. Retrieved from. https://www.who.int/mediacentre/ news/releases/2016/air-pollution-rising/en/\#.WrrLXYrQNwg. mendeley.

19. Pope III, C. A., \& Dockery, D. W. (2006). Health effects of fine particulate air pollution: lines that connect. Journal of the Air and Waste Management Association., 56(6), 709-742.

20. Lelieveld, J., Evans, J. S., Fnais, M., Giannadaki, D., \& Pozzer, A. (2015). The contribution of outdoor air pollution sources to premature mortality on a global scale. Nature, 525(7569), 367-371.

21. Pollution made COVID-19 worse. Now, lockdowns are clearing the air. (2020). National Geographic. https://www.nationalgeo graphic.com/science/2020/04/pollution-made-the-pandemic-worsebut-lockdowns-clean-the-sky/.

22. Wu, X., Nethery, R.C., Sabath, B.M., Braun, D., \& Dominici, F. (2020) Exposure to air pollution and COVID-19 mortality in the United States. medRxiv. Preprint posted April. Vol. 7.

23. Lolli, S., Chen, Y., Wang, S. et al. (2020). Impact of meteorological conditions and air pollution on COVID-19 pandemic transmission in Italy. Scientific Reports, 10, 16213. https://doi. org/10.1038/s41598-020-73197-8.

24. Pani, S. K., Lin, N. H., \& RavindraBabu, S. (2020). Association of COVID-19 pandemic with meteorological parameters over Singapore. Science of The Total Environment., 740, 140112.

25. Bolaño-Ortiz, T. R., Camargo-Caicedo, Y., Puliafito, S. E., Ruggeri, M. F., Bolaño-Diaz, S., Pascual-Flores, R., et al. (2020). Spread of SARS-CoV-2 through Latin America and the Caribbean region: a look from its economic conditions, climate and air pollution indicators. Environmental Research., 191, 109938.

26. Xie, J., \& Zhu, Y. (2020). Association between ambient temperature and COVID-19 infection in 122 cities from China. Science of the Total Environment, 724, 138201.

27. Zalakeviciute, R., Vasquez, R., Bayas, D., Buenano, A., Mejia, D., Zegarra, R., et al. (2020). Drastic improvements in air quality in ecuador during the COVID-19 outbreak. Aerosol and Air Quality Research, 20, 1783-1792.

28. Menebo, M. M. (2020). Temperature and precipitation associate with Covid-19 new daily cases: A correlation study between weather and Covid-19 pandemic in Oslo Norway. Science of The Total Environment., 737, 139659.
29. Ruiz, M. O., Chaves, L. F., Hamer, G. L., Sun, T., Brown, W. M., Walker, E. D., et al. (2010). Local impact of temperature and precipitation on West Nile virus infection in Culex species mosquitoes in northeast Illinois, USA. Parasites and vectors, $3(1), 19$.

30. Wang, G., Minnis, R. B., Belant, J. L., \& Wax, C. L. (2010). Dry weather induces outbreaks of human West Nile virus infections. BMC infectious diseases., 10(1), 38.

31. Kuchler, T., Russel, D., \& Stroebel, J. (2020). The geographic spread of COVID-19 correlates with structure of social networks as measured by Facebook. National Bureau of Economic Research. Report No.: 0898-2937.

32. Cho, Y. (2020). Blue skies return to China as coronavirus cuts coal consumption. Nikkei Asian Review. Retrieved from. https:// asia.nikkei.com/Spotlight/Coronavirus/Blue-skies-return-to-Chinaas-coronavirus-cuts-coal-consumption.

33. Wang, P., Chen, K., Zhu, S., Wang, P., \& Zhang, H. (2020). Severe air pollution events not avoided by reduced anthropogenic activities during COVID-19 outbreak. Resources, Conservation and Recycling., 158, 104814.

34. Faridi, S., Yousefian, F., Niazi, S., Ghalhari, M. R., Hassanvand, M. S., \& Naddafi, K. (2020). Impact of SARS-CoV-2 on ambient air particulate matter in Tehran. Aerosol and Air Quality Research, 20, 1805-1811.

35. Chen, Q. X., Huang, C. L., Yuan, Y., \& Tan, H. P. (2020). Influence of COVID-19 event on air quality and their association in Mainland China. Aerosol and Air Quality Research, 20, $1541-1551$.

36. Xu, K., Cui, K., Young, L. H., Wang, Y. F., Hsieh, Y. K., Wan, S., \& Zhang, J. (2020). Air quality index, indicatory air pollutants and impact of COVID-19 event on the air quality near central China. Aerosol and Air Quality Research, 20, 1204-1221.

37. Filonchyk, M., Hurynovich, V., Yan, H., Gusev, A., \& Shpilevskaya, N. (2020). Impact Assessment of COVID-19 on Variations of $\mathrm{SO}_{2}, \mathrm{NO}_{2}, \mathrm{CO}$ and $\mathrm{AOD}$ over East China. Aerosol and Air Quality Research., 20, 1530-1540.

Publisher's Note Springer Nature remains neutral with regard to jurisdictional claims in published maps and institutional affiliations. 